\title{
КОНКУРЕНТНИЙ СТАТУС УКРАЇНСЬКИХ УНIВЕРСИТЕТІВ: ЄВРОПЕЙСЬКИЙ ТА ГЛОБАЛЬНИЙ ВИМІР
}

\author{
Наукова доповідь на методологічному семінарі НАПН України \\ "Шляхи і механізми підвищення конкурентоспроможності \\ університетів України» 19 листопада 2020 р. \\ https://doi.org/10.37472/2707-305X-2020-2-2-13-9
}

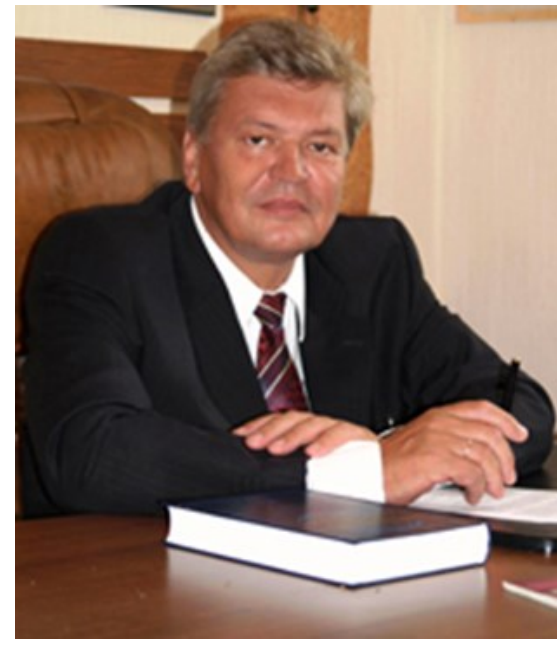

ЛУК'ЯНЕНКО

Дмитро Григорович

доктор економічних наук, професор, член-кореспондент НАПН України, ректор Державного вищого навчального закладу «Київський національний економічний університет імені Вадима Гетьмана», м. Київ, Україна

Анотація. На основі узагальнення світового досвіду і емпіричного аналізу висвітлено проблему конкурентності національних систем вищої освіти і рейтингового позиціонування університетів. Показано ключову роль університетів у глобальній екосистемі, коли головним фактором розвитку і прогресу стає інтелектуальний капітал. Підтверджено слабкі конкурентні позиції українських університетів у глобальних рейтингах $i$ виявлено потенціал їх нарощування. Проілюстровано зарубіжний досвід державної підтримки університетів у країнах - інноваційних лідерах. Ідентифіковано виклики і можливості цифрової трансформації університетів у форматі мережевоплатформної конкуренції на глобальному ринку науково-освітніх послуг. Аргументовано організаційний дизайн конкурентної моделі сучасного університету. Обгрунтовано критично важливі контури і стратегічні орієнтири розвитку університетів у парадигмі «Вища освіта 4.0».

Ключові слова: глобальна конкурентоспроможність; глобальна інтелектуалізація; інтелектуальний капітал; системи вищої освіти; університети; моніторинг; иифрова трансформація університетів; глобальні мережі; конкуренція платформ; освітня парадигма 4.0.

Вступ. На сучасному етапі розвитку економіки університети можуть ефективно функціонувати і бути конкурентоспроможними лише за умов постійного нарощування інтелектуального капіталу в інституціоналізованій глобальній екосистемі (рис. 1).

У глобалізованому ринковому суспільстві саме університети стали центрами генерування, накопичення і передачі знань та інформації, формування і концентрації персоніфікованого інтелектуального ресурсу (Лук'яненко \& Поручник, 2011; Лук'яненко \& Лук'яненко, 2015). У провідних країнах світу університети, насамперед дослідницькі, відіграють ключову роль не тільки у продукуванні нових знань, а й проривних інновацій (Павленко \& Антонюк, 2014). Світовий досвід доводить, що вища освіта та інновації є рушіями глобальної конкурентоспроможності, що підтверджує висока кореляція позицій країн-лідерів за індексом глобальної конкурентоспроможності та їхнього місця в глобальних рейтингах інновацій і національних систем вищої освіти.

Університети як базові елементи національних інноваційних систем стають об'єктами особливої дослідницької уваги, різнопланових оцінок, моніторингів і рейтингування.

Аналіз присутності вітчизняних університетів у глобальних рейтингах показує їх вкрай недостатні конкурентні позиції навіть 


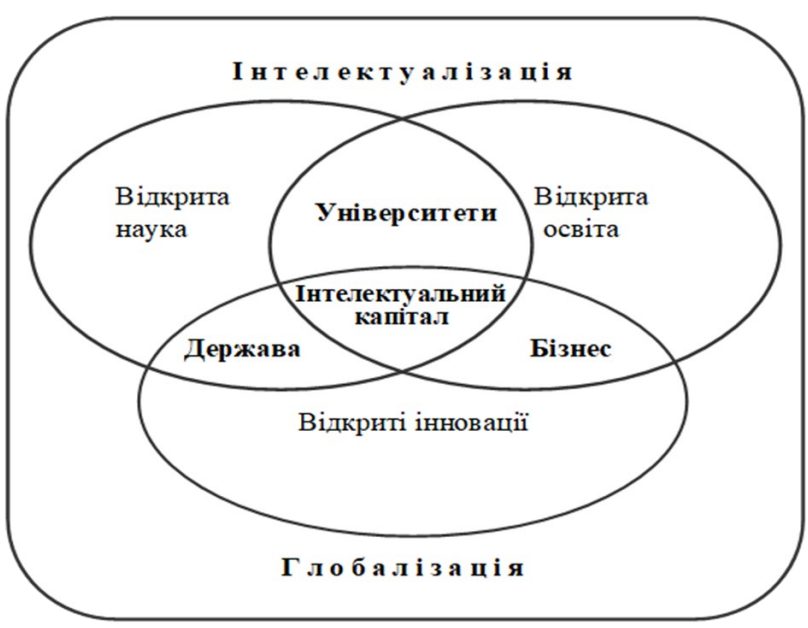

Рис. 1. Екосистема інтелектуалізації глобального економічного розвитку

порівняно з країнами Центральної та Східної Європи (ЦСЄ) (табл. 1) і невисоку рейтингову динаміку (рис. 2).

Таблиия 1

Університети країн Центральної та Східної Європи в глобальних рейтингах

\begin{tabular}{|c|c|c|c|c|}
\hline Крайна & $\begin{array}{c}\text { ARWU } \\
\text { Toп-1000/y } \\
\text { базах дапих }\end{array}$ & $\begin{array}{c}\text { U.S. News } \\
\text { Tоп- } \\
\text { 1000/загалом } \\
\text { у рейтингу }\end{array}$ & $\begin{array}{c}\text { THE } \\
\text { Топ- } \\
\text { 1000/загалом } \\
\text { у рейтингу }\end{array}$ & $\begin{array}{c}\text { QS } \\
\text { Tоп-1000/ y } \\
\text { рейтингу }\end{array}$ \\
\hline Туреччина & $12 / 13$ & $15 / 39$ & $11 / 34$ & $9 / 45$ \\
\hline $\mathbf{P \Phi}$ & $11 / 11$ & $12 / 14$ & $15 / 39$ & $25 / 87$ \\
\hline Польща & $9 / 12$ & $11 / 25$ & $4 / 14$ & $16 / 23$ \\
\hline Чехія & $7 / 7$ & $6 / 10$ & $5 / 17$ & $9 / 18$ \\
\hline Угоршина & $5 / 6$ & $6 / 7$ & $5 / 8$ & $6 / 11$ \\
\hline Румунія & $2 / 4$ & $3 / 10$ & $2 / 9$ & $2 / 17$ \\
\hline Словаччина & $1 / 1$ & $2 / 3$ & $0 / 4$ & $3 / 6$ \\
\hline Болгарія & $1 / 1$ & $1 / 2$ & $0 / 1$ & $1 / 3$ \\
\hline Україна & $0 / 4$ & $0 / 1$ & $0 / 6$ & $6 / 18$ \\
\hline $\begin{array}{l}\text { Джерело: } \\
\text { рейтингів. }\end{array}$ & Складено & зтором & даними & глобал \\
\hline
\end{tabular}

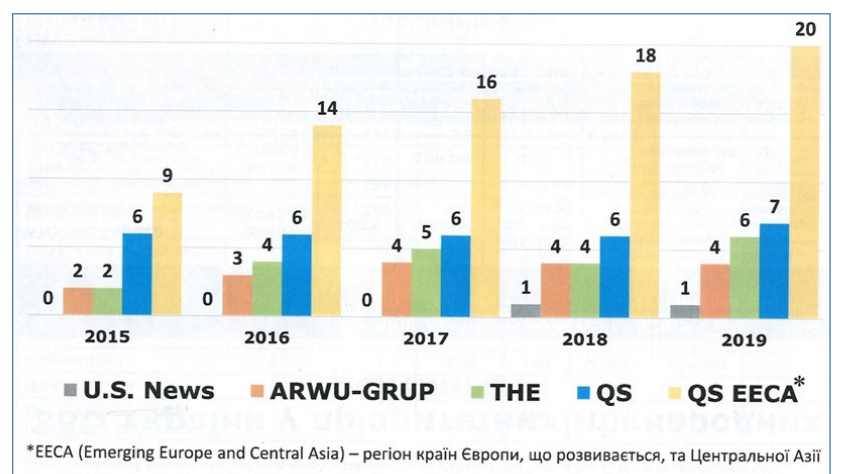

Рис. 2. Динаміка кількості 3ВО

України у глобальних рейтингах

Джерело: Васильєв, 2020, с. 6.

Ураховуючи, з одного боку, цільову спрямованість та критеріальні обмеження глобальних рейтингів університетів і усталені провідні місця у них обмеженого кола університетів світового рівня, а з іншого боку, багаторічну конкурентну неспроможність навіть найкращих українських уні- верситетів, доцільно зосередити дослідницький інтерес на універсальних об'єктивних і суб'єктивних факторах лідерських і аутсайдерських рейтингових позицій у контексті новітніх викликів і можливостей.

Зарубіжний досвід державної підтримки університетів. Справедливо, на нашу думку, вважається, що найбільш конкурентоспроможними є системи вищої освіти, а рейтинговими - університети країн, які мають тривалу успішну історію їх послідовного розвитку із постійною підтримкою кращих практик у цій сфері. Яскравим прикладом традиції потужної послідовної державної підтримки освітнього та дослідного сектору $\in$ США. Так, сьогодні частка державних витрат на фінансування досліджень в університетах США становить від 37,1\% до 93,3\% та залишається відносно сталою протягом останніх років. Зокрема, Гарвардський університет і Массачусетський технологічний інститут спрямовують близько 50\% свого бюджету на наукову діяльність і переважна частина - це державні кошти, отримані на конкурсній основі. Також слід відзначити, що у США державне фінансування досліджень покриває і непрямі витрати у розмірі 35\%-55\% від прямих витрат. Загалом університети США, насамперед дослідницькі, завжди мали і мають належне фінансування, інноваційну статусність і суспільну престижність. Це сповна стосується і провідних європейських країн, насамперед Великої Британії, Німеччини, Франції. Частка державних видатків у середньому в країнах ОЕСР становить 90\% для початкової, середньої, а також професійної за межами вищої освіти та близько 68\% - для вищої освіти.

В останні десятиріччя стратегічна державна підтримка відіграє особливо важливу роль і в системах вищої освіти нових індустріальних країн. Для такої державної підтримки притаманно багато спільних рис, серед яких плановість, використання найкращого зарубіжного досвіду, фокусування місії університетів на інноваційному прогресі. Наприклад, система вищої освіти Сінгапуру, перейнявши багато британських традицій, зазнала істотних трансформацій під час правління Лі Куан Ю, стратегія якого базувалась на прагненні «розвинути єдиний природний ресурс Сінгапуру - його народ». Максимальне використання ментальних традицій, комплексний і водночас креативний реформаторський підхід дав Сінгапуру можливість швидко створити одну з найсучасніших і найбільш конкурентоспроможних систем вищої освіти (четверте місце в рейтингу Uni- 
versitas 21 у 2020 р. та перше - за Глобальним індексом конкурентоспроможності). За дослідженням експертів Всесвітнього економічного форуму, уряд Сінгапуру вважається найбільш «готовим до майбутнього», що є однією із фундаментальних основ нарощення конкурентоспроможності в умовах Четвертої промислової революції.

Значних якісних змін в останні 25 років зазнала і система вищої освіти Південної Кореї, коли завдяки цілеспрямованому реформуванню і потужній державній підтримці університетів країна істотно наростила інноваційний потенціал і зайняла 24 місце в рейтингу Національних систем вищої освіти Universitas 21 у 2020 р. Програма розвитку вищої освіти «Brain Korea 21 Plus» (2013-2019 рр., загальний обсяг фінансування 2 млрд дол. США) мала на меті якісний стрибок системи освіти і дослідницького потенціалу країни. На цьому етапі політика держави фокусувалась на розвитку дослідницьких університетів світового класу, підвищенні якості освіти і досліджень.

За останні 20 років вражаючими є результати у нарощенні потенціалу й конкурентоспроможності системи вищої освіти Китаю. У 2020 р. вона посіла 26 місце серед 50 країн у рейтингу національних систем вищої освіти Universitas 21, і 42 з 132 країн у рейтингу конкурентоспроможності талантів (у 2017 р. - 54). Серед програм навчання домінують технічні, математичні, наукові дисципліни. За значної державної підтримки пришвидшеними темпами зростала міжнародна академічна мобільність і співпраця з іноземними установами, що привело до вагомого нарощення диверсифікованості вищої освіти в Китаї і суттєвого прогресу провідних китайських університетів, котрих у країні налічується близько трьох тисяч. Рівень залученості молоді до вищої освіти, що вважається надзвичайно престижною у країні (конкурс сягає 200-300 осіб на місце), збільшився з 21\% у 2006 р. до 51,6\% у 2019 р. Поширеною стала практика цільового фінансування отримання вищої освіти підприємствами і організаціями, кредитування, навчання без відриву від виробництва. Показово, що за останні роки кількість китайських університетів світового класу зростала найшвидше порівняно з рештою країн світу: із 13 у 2009 р. до 51 у рейтингу QS 2021.

Прискорений розвиток університетів і їх перетворення на провідні світові дослідницькі наукові й освітні центри відбувався за значної державної підтримки, зокрема в рамках ініціатив «Проєкт 211» (1995 р., досягнення університетами лідерських світових позицій через удосконалення навчальних програм відповідно до міжнародних стандартів і принципів міждисциплінарності, нарощення дослідницького потенціалу шляхом розвитку професорсько-викладацького складу і академічної мобільності, інфраструктурних реформ у системі вищої освіти і розвитку електронної і дистанційної освіти), «Проєкт 985» (1998 р., нарощення фінансування кращих університетів/факультетів 3 метою посилення їхньої дослідницької продуктивності тощо). Однозначно, провідні китайські університети реалізують стратегії розширення власної присутності в глобальному академічному просторі, приваблюючи науковців і студентів 3 усього світу, а також відкриваючи власні кампуси в інших країнах Азії.

У 2017 р. Міністерство освіти та Національна комісія розвитку і реформ КНР представили Тринадцятий п'ятирічний план розвитку освіти, у якому деталізовано стратегію розвитку університетів світового класу 2.0 з визначенням коротко-, середньо- та довгострокових цілей. У рамках плану «Університети світового класу 2.0» передбачено фінансування обсягом у 40 млрд юанів (понад 6 млрд дол.). Основним компонентом у фінансуванні системи освіти є державні витрати на рівнях Центрального та місцевих урядів (80\% у 2018 р.). Згідно зі звітом Міністерства освіти КНР, у 2018 р. сукупні витрати на освіту становили 4,6 трлн юанів (695,9 млрд дол., 5\% ВВП), зокрема державні витрати - 3,7 трлн юанів (на вищу освіту - 1,2 трлн юанів (у перерахунку на одного студента - 36,3 тис. юанів). У 2019 р. витрати на освіту зросли на 6\% (5,2\% від сукупних витрат державного бюджету).

Як прогнозують експерти дослідницького інституту Battelle, державні витрати у вищій освіті будуть у подальшому зростати, і особливо пришвидшено - в Китаї (рис. 3).

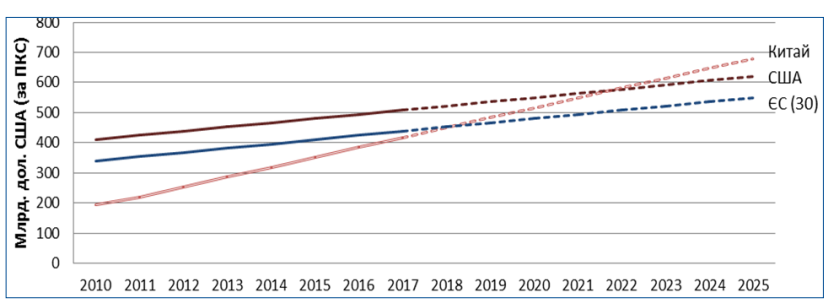

Рис. 3. Витрати на дослідження у США, ЄС і Китаї, 2010-2017 pp. (2018-2025 pp. - прогноз)

Виклики і нові можливості цифровізації університетської освіти. Вражаючим феноменом XXI ст. 
стала безпрецедентна цифровізація усіх сфер професійної і суспільної діяльності, ключовими елементами і водночас драйверами якої $є$ цифрові дані й технології, цифрова платформа, інфраструктура та цифрове мислення. За експертними оцінками сьогодні цифрова економіка становить до 16\% від глобального ВВП, а їі масштаби до 2035 р. прогнозуються на рівні 16 трлн дол. США. (Хаустов, 2019).

Мотивація, масштаби і динаміка цифровізації університетів, на нашу думку, зумовлені:

- по-перше, вимогами і новими викликами зовнішнього середовища із надшвидкою масштабізацією застосування IKT у будь-якій професійній діяльності, регуляторних національних і міжнародних практиках, повсякденній комунікації і соціалізації;

- по-друге, різким зростанням глобальної конкуренції серед університетів за абітурієнтів на освітньому ринку та серед випускників на ринку праці, що потребує активізації маркетингу та брендингу постійної оптимізації управлінських процесів для ефективної внутрішньої і зовнішньої мережевої взаємодії;

- по-третє, новими цивілізаційними реаліями, коли студентами стають представники нового цифрового Z-покоління, мотиваційні, життєві, а в подальшому і професійні цінності якого «не вписуються» у традиційні формати освіти, праці, норми і стилі поведінки (Колот \& Герасименко, 2020).

Очікуваними пріоритетними перевагами цифровізації освіти за анкетними дослідженнями студенти вважають: «свободу мислення і особистої ідентичності; персоніфікацію цифрових технологій під особисті смаки; доступність будь-якої інформації; транспарентність і чесність професійної та соціальної взаємодії; відчуття себе органічною частиною «освіти задоволень»; прямий взаємозв'язок і співробітництво з іншими суб'єктами освіти; швидкість і оперативність пошуку відповідей на будь-які запитання; інноваційність у освіті, професійній кар'єрі й особистому житті» (Тапскотт, 2017; Дадалко, Дадалко, \& Сидоренко, 2020, с. 61).

Важливо усвідомлювати, що якісні зміни на ринку праці , коли важливими стають не лише дипломи, а й набуті у мережах неформальної освіти компетенції, зумовлюють необхідність швидкої реакції університетів для їх конкурентної здатності надавати новітні компетенції (Колот \& Герасименко, 2020). Серед них не тільки інформаційно- цифрова адекватність студентів і випускників, а також: глобальне інноваційне мислення, обов'язкова креативність; здатність до колективного співробітництва; самостійність у виборі траєкторії розвитку; орієнтація на постійне зростання; фізична і психологічна гармонійність; здатність до співпереживання; адаптивність до змін і форсмажорів та наймопридатність за нетрадиційної зайнятості на умовах неповного робочого часу або неповної зайнятості чи строкових трудових договорів (це особливо важливо під час пандемії); тимчасова, непостійна зайнятість, зокрема запозичена праця; вторинна зайнятість; дистанційна зайнятість; зайнятість на основі договорів цивільно-правового характеру; неформальна зайнятість, зокрема самозайнятість; незареєстрована зайнятість у формальному секторі) (Колот \& Герасименко, 2020).

Стратегії університетів цифрової доби формуються у глобальному ландшафті державних, регіональних і секторальних стратегій (рис. 4).

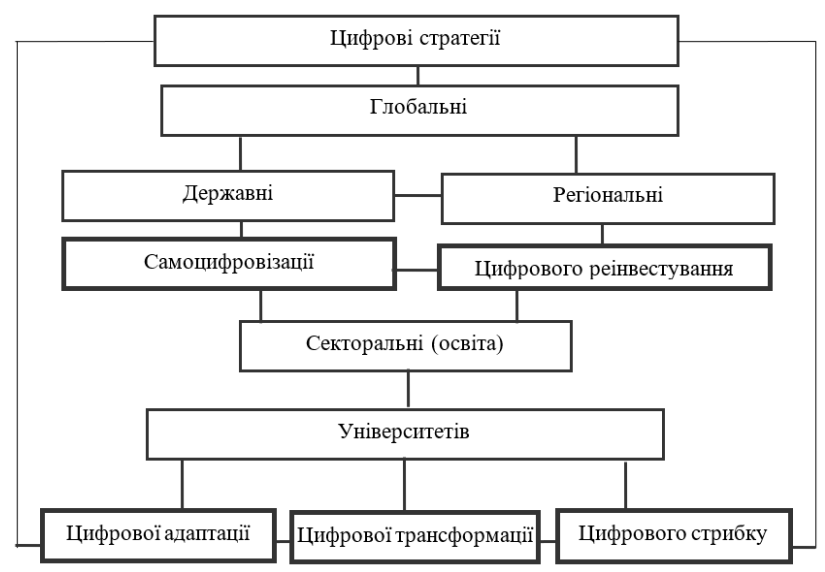

Рис. 4. Цифрова стратегія університетів

Прикладом цифрової трансформації університету $є$ стратегія Київського національного економічного університету імені Вадима Гетьмана, де у 2017 р. розпочато проєкт «DIGITAL UNIVERSITY», загальна концепція якого розроблена з урахуванням сучасних вимог і конкурентних переваг діджиталізації (рис. 5).

У проєкті «DIGITAL UNIVERSITY» передбачаєTься системна діджиталізація IKT-платформи Університету за напрямами:

1) комунікація та уніфікація процесів обміну даними через оцифрування усіх процесів діяльності Університету;

2) стандартизація представлення інформації та впровадження наскрізної системи електронного документообігу, імплементація концепції «цифрових» робочих місць; 


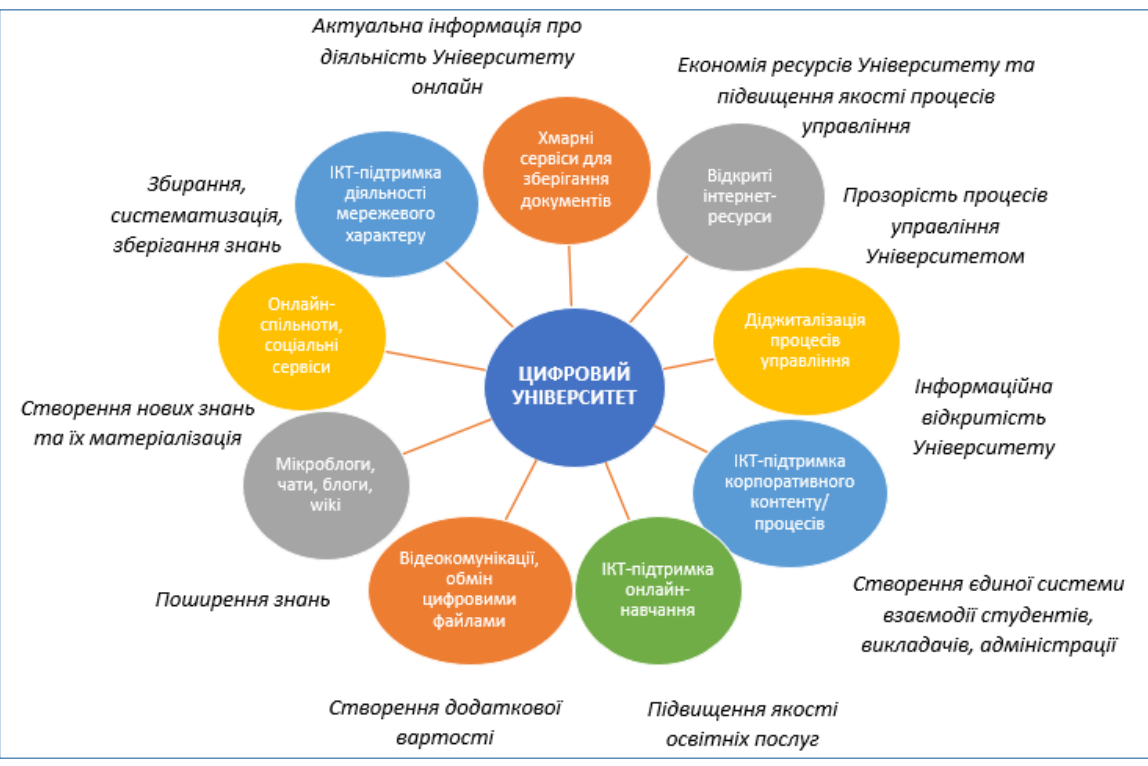

Рис. 5. Діджиталізація процесів діяльності університетів

\begin{tabular}{|c|c|c|c|}
\hline \multicolumn{4}{|c|}{ 1. ВИЗНАЧЕННЯ ПРОБЛЕМ РОЗБУДОВИ ЦИФРОВОГО УНВЕРСИТЕТУ } \\
\hline 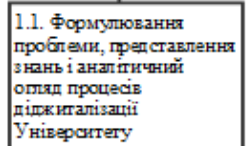 & 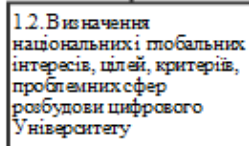 & 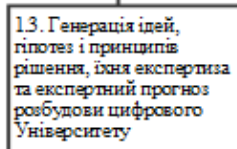 & 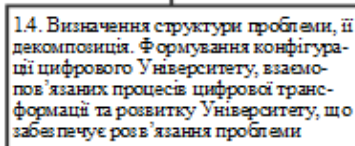 \\
\hline
\end{tabular}

2. ВИЗНАЧЕННЯ ТА АНАЛВ ЗАДАЧ РОЗБУДОВИ ЦИФРОВОГО УНВВЕРСИТЕТУ

2.1. Достіпження процесів піпкиталізапіі в контексті ровбудови цифрового університетута постановка запач пля розв' 'занни проблеми

2.2. Ф ормуванни системи ключових інпикаторів взаемопов'тваник процесів забезпечення ровбуд ови цифрового університету

2.3. Визначення IKT-забезпечення для ровв' же ання запач діпкиталізаціі в контексті ровбудови щифрового університету

\section{3. ОБГРРУНТУВАННЯ ОПТИМАЛЬНИХ ВАРІАНТ ІВ РОЗВ'ЯЗАННЯ ПРОБЛЕМИ}

\section{1. Формування

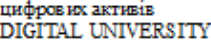

3.3. Застосування плобальнихцифрових мереж Intemet of Thing

\section{4. РЕ ЗУ ТЬТАТИВНІСТ ЗАБЕ ЗПЕ ЧЕ НН Я ПРОШЕ СІВ РОЗБУДОВИ ШИФРОВОГО УНІВЕ РСИТЕ ТУ}

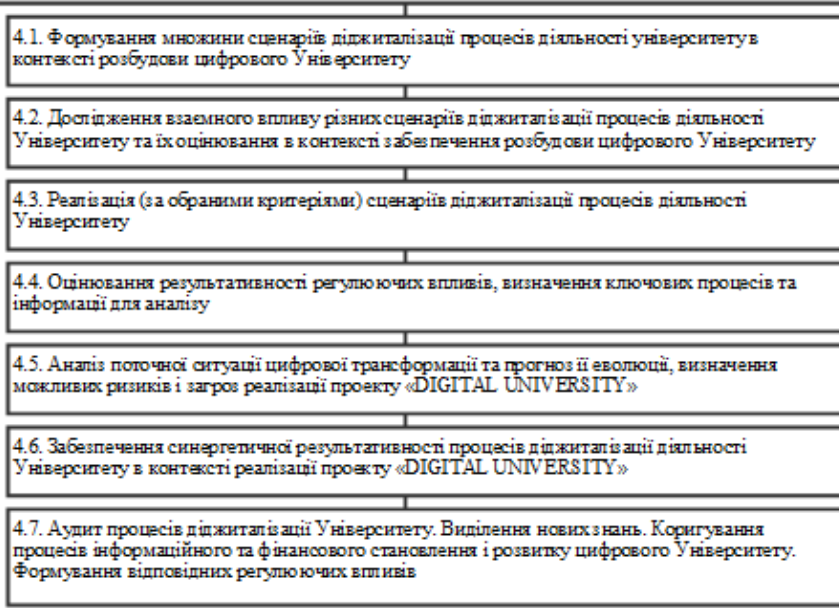

Рис. 6. Концептуальний формат розбудови цифрового Університету

3) відкрите середовище розроблення сервісів подання / передавання / представлення інформації та інформаційна підтримка можливості одночасної роботи з даними 3 різних інформаційних джерел (рис. 6).

Загалом ми вважаємо, що за цільовою орієнтацією, ключовими завданнями і архітектурою проєкт цифровізації КНЕУ імені Вадима Гетьмана $€$ актуальним, своєчасним і реальним у руслі інноваційних і культурних перетворень при переході на нову освітню модель XXI ст.

На нашу думку, саме цифрова трансформація університетів як сучасна передумова їх конкурентоспроможності та високої рейтинговості $\epsilon$ етапом еволюції парадигми вищої освіти із переосмисленням місії університетів - зі створення, накопичення і поширення знань на рівні освіти 1.0 у підготовку системно і креативно мислячих інноваторів, здатних розвиватись у середовищі глобальних мереж на рівні освіти 4.0 (табл. 2) (Антонюк та ін., 2017, c. 14).

Конкурентоспроможні університети автономно адаптують до нових умов і викликів свої основні функції, одночасно створюючи можливості для виходу на ринки нових для себе видів освітніх послуг, наукових досліджень, а також нові географічні ринки. При цьому в більшості європейських країн, зокрема в Німеччині, Франції, Італії та ін., університети орієнтуються на пріоритетні напрями розвитку, визначені в національних стратегіях (програмах) у сфері досліджень та іннова- 
Еволюція парадигм вищої освіти

\begin{tabular}{|c|c|c|c|c|}
\hline $\begin{array}{c}\text { Ключові } \\
\text { виміри }\end{array}$ & Освіта 1.0 & Освіта 2.0 & Освіта 3.0 & Освіта 4.0 \\
\hline Місія & $\begin{array}{l}\text { • надання системних } \\
\text { стандартизованих знань; } \\
\text { • масовість освіти; } \\
\text { проведення епізодичних } \\
\text { фундаментальних } \\
\text { досліджень }\end{array}$ & $\begin{array}{l}\text { • надання спеціалізованих } \\
\text { знань і навичок, } \\
\text { підвищення рівня } \\
\text { фінансування та якості } \\
\text { освіти; } \\
\text { • проведення прикладних } \\
\text { досліджень }\end{array}$ & $\begin{array}{l}\text { • надання } \\
\text { високоякісних освітніх } \\
\text { послуг; } \\
\text { • проведення спільних } \\
\text { досліджень } 3 \\
\text { промисловістю та } \\
\text { урядом }\end{array}$ & $\begin{array}{l}\text { • надання глобальних } \\
\text { компетенцій і навичок; } \\
\text { • навчання базується } \\
\text { на дослідженнях, } \\
\text { участі в інноваційних } \\
\text { процесах }\end{array}$ \\
\hline $\begin{array}{l}\text { Мiсие } \\
\text { навчання }\end{array}$ & $\begin{array}{l}\text { спеціально відведені } \\
\text { навчальні приміщення }\end{array}$ & $\begin{array}{l}\text { навчальні приміщення, } \\
\text { онлайн-платформи }\end{array}$ & $\begin{array}{l}\text { навчальні приміщення, } \\
\text { онлайн-платформи }\end{array}$ & глобальна мережа \\
\hline $\begin{array}{l}\text { Технології } \\
\text { навчання }\end{array}$ & $\begin{array}{l}\text { технології майже не } \\
\text { використовуються }\end{array}$ & $\begin{array}{l}\text { епізодичне використання } \\
\text { технологій, Інтернету }\end{array}$ & $\begin{array}{l}\text { активне використання } \\
\text { технологій, Інтернету }\end{array}$ & $\begin{array}{l}\text { тісна інтеграція } \\
\text { технологій і їх щоденна } \\
\text { модифікація }\end{array}$ \\
\hline $\begin{array}{l}\text { Методики } \\
\text { навчання }\end{array}$ & $\begin{array}{l}\text { від викладача - } \\
\text { студенту, } \\
\text { запам'ятовування }\end{array}$ & $\begin{array}{l}\text { освітній діалог, } \\
\text { урізноманітнення } \\
\text { навчального процесу }\end{array}$ & $\begin{array}{l}\text { обмін знаннями, освіта } \\
\text { впродовж життя }\end{array}$ & $\begin{array}{l}\text { спільне вироблення } \\
\text { інновацій, } \\
\text { безперервна освіта }\end{array}$ \\
\hline $\begin{array}{l}\text { Результати } \\
\text { освітнього } \\
\text { процесу }\end{array}$ & $\begin{array}{l}\text { Випускники орієнтовані } \\
\text { на виконання } \\
\text { професійних функцій }\end{array}$ & $\begin{array}{l}\text { випускники володіють } \\
\text { необхідними } \\
\text { компетенціями }\end{array}$ & $\begin{array}{l}\text { випускники володіють } \\
\text { критичним мисленням }\end{array}$ & $\begin{array}{l}\text { випускники здатні до } \\
\text { креативності, } \\
\text { створення інновацій та } \\
\text { їх комерціалізації }\end{array}$ \\
\hline
\end{tabular}

Джерело: Антонюк та ін., 2017, с. 14.

цій, що забезпечує їм належне фінансування на конкурсній основі.

Конкурентна модель університету в освітній парадигмі 4.0 представлена на рис. 7.

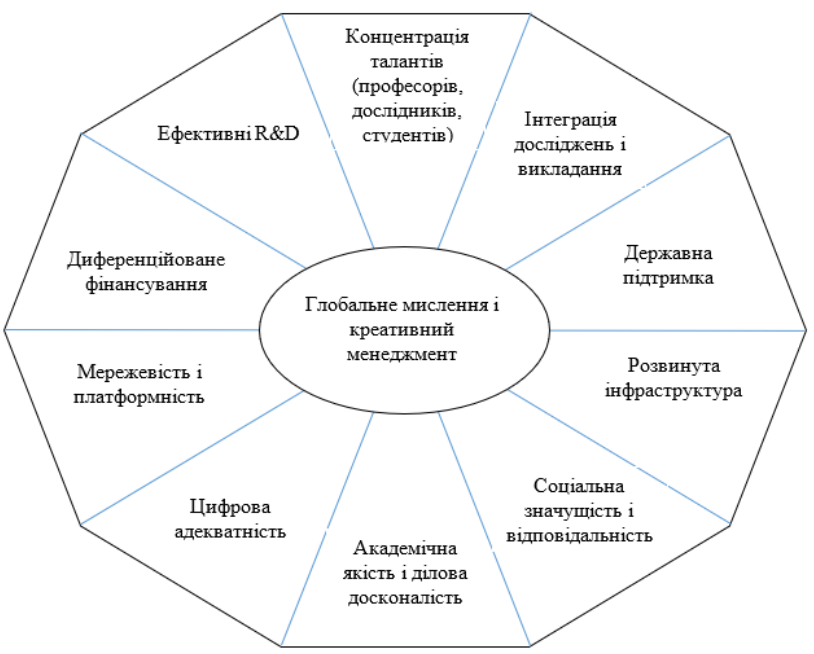

Рис. 7. Конкурентна модель Університету 4.0

Характерною рисою більшості країн, що входять до рейтингу Universitas 21, а також провідних університетів $\epsilon$ реалізація цілеспрямованої політики у сфері управління якістю освіти та ділової досконалості як базису внутрішньої і глобальної конкурентоспроможності. (Лук'яненко та ін., 2019).

Зазначимо, що в США домінує модель Болдріджа, європейські країни (Німеччина, Франція, Іспанія) використовують модель EFQM, а азійські країни та Японія - KAIZEN.
У форматі моделі EFQM Україні потрібно виявляти зовнішні виклики і ефективно реагувати на них, цілеспрямовано створювати спільні цінності зі споживачами на основі вивчення їх інтересів і залучення до прийняття рішень. Також мають покращуватись умови для залучення кращих професіоналів до процесу створення наукової продукції і надання освітніх послуг при сприянні їх особистісній і професійній кар'єрі. Пріоритетом є розвиток мотиваційних механізмів постійної інноватизації освіти через генерування, поширення і комерціалізацію знань, пропагування інтелектуально-креативних цінностей і суспільних статусів.

Висновки. У сучасній парадигмі розвитку, де домінує техноглобалізм, економічна і політична влада все більше концентруються у руках виробників знань та інформації, забезпечуючи їм глобальне конкурентне лідерство. Акселераторами інноваційного поступу $є$ університети як ключові інститути вищої освіти, що генерують інтелектуальний капітал. Сучасним імперативом їх розвитку стає забезпечення підготовки глобально конкурентоспроможних фахівців у процесі навчання протягом усього життя. В умовах розгортання промислової Революції 4.0 державна підтримка вищої освіти і наукових досліджень є критично значущою для інноваційного розвитку та конкурентоспроможності, що підтверджується успішними практиками країн-лідерів технологічного, економічного і соціального прогресу.

Глобально неконкурентна система вищої освіти України має значний потенціал і передумови для становлення високорейтингових університе- 
тів. Так, за Глобальним освітнім дайджестом IHституту статистики ЮНЕСКО, вона належить до лідерів у поширенні вищої освіти серед країн ЦСЄ (значення індексу міжнародні експерти оцінюють у 38\%). У 2019 р. за Індексом глобальної конкурентоспроможності Україна посіла 85 місце, тоді як за Глобальним Інноваційним індексом (INSEAD, WIPO) - 47, у Рейтингу національних систем вищої освіти (Universitas 21) - 38 місце (у рейтингу 2020 р. - 36 місце). Основними бар'єрами на шляху ефективної реалізації інтелектуального потенціалу є лише декларативна провідна позиція науково-освітньої сфери у політикоекономічних пріоритетах і цілях, критична нестача державної фінансової підтримки кількісно і структурно неоптимізованих українських університетів, неефективна модель управління сектором вищої освіти, коли дискредитується автономія університетів, знижується матеріальний і статусний імідж науково-педагогічних працівників.

Сьогодні Україна потребує переосмислення свого місця у глобальному і європейському економічному просторі, пошуку й реалізації нестандартних шляхів прискореного інноваційного зростання, спрямованого на підвищення рівня добробуту та поліпшення позицій країни в глобальних рейтингах конкурентоспроможності. Ураховуючи визначальну роль сфери вищої освіти в технологічному, економічному і суспільному розвитку, ключовими партнерами для уряду України у досягненні таких цілей мають стати конкурентоспроможні на глобальному рівні університети як фундаментальні інституційні драйвери національного прогресу.

\section{СПИСОК ВИКОРИСТАНИХ ДЖЕРЕЛ}

Антонюк, Л., Ільницький, Д., Барабась Д., \& Сандул, М. (2017). Міжнародна конкурентна диспозиція національних систем вищої освіти. Міжнародна економічна політика, (2), 7-39. https://bit.ly/3nk8gno
Васильєв, А. (2020). Роль рейтингів у стратегії розвитку університетів. Сумський державний університет. https://cutt.ly/5jr93Pv

Дадалко, В., Дадалко, С., \& Сидоренко, С. (2020). Взаимодействие секторов высшего образования, бизнеса, государства и общества как условие национальной безопасности при формировании информационной экономики. Общество и экономика, (5), 54-67. http://elib.fa.ru/art2020/bv814.pdf

Колот, А.М., \& Герасименко, О.О. (2020а). Покоління Z і соціально-трудова платформа «Праця 4.0»: імперативи взаємодії. Демографія та сочіальна економіка, (2), 103-138. https://dse.org.ua/arhcive/40/_7.pdf

Колот, А.М., \& Герасименко, О.О. (2020b) Сфера праці в умовах глобальної соціоекономічної реальності 2020: виклики для України. Київ: Фонд ім. Фрідріха Еберта. http://library.fes.de/pdf-files/bueros/ ukraine/16344.pdf

Колот, А.М., \& Герасименко, О.О. (2020с). Цифрова трансформація та нові бізнес-моделі як детермінанти формування економіки нестандартної зайнятості. Соціально-трудові відносини: теорія і практика, 10(1), 3354. https://ir.kneu.edu.ua/handle/2010/34139

Лук'яненко, Д.Г., \& Поручник, А.М. (2011). Інноваційний ресурс економічного розвитку України: інтелектуальна місія університетів. Вища школа, (12).

Лук'яненко, Д.Г., Антонюк, Л.Л., Василькова, Н.В., Ільницький, Д.О. та ін. (2019). Конкурентні моделі управління якістю вищої освіти у ХXI столітmі : монографія. (Д.Г. Лук'яненко, Л.Л. Антонюк, ред). Київ: КНЕУ.

Лук'яненко, Д.Г., \& Лук'яненко, О.Д. (2015). Інтелектуальний капітал у глобальній економіці: методологічна ідентифікація. Ринок цінних паперів України, (9-10), 3544.

Олейникова, Ю.А. (2019). Вызовы и модели развития бизнеса в условиях прогрессии цифровой экономики. Вопросы инновационной экономики, 9(4), 1415-1426. https://1economic.ru/lib/41294

Павленко, А.Ф., \& Антонюк, Л.Л. (ред). (2014). Дослідницькі університети: світовий досвід та перспективи розвитку в Україні : монографія. Київ: КНЕУ.

Тапскотт, А. (2017). Технология блокчейн, то что движет финансовой революцией сегодня. Москва: Эксмо.

Хаустов, В. (2019). Цифрова економіка: як тобі служиться? ZN.UA, (39). https://bit.ly/3rh7oJe

COMPETITIVE STATUS OF UKRAINIAN UNIVERSITIES: EUROPEAN AND GLOBAL DIMENSION

Scientific report at the methodological seminar of the National Academy of Educational Sciences of Ukraine

"Ways and Mechanisms of Increasing the Competitiveness of Universities", November 19, 2020

\section{Dmytro Lukianenko}

DSc in Economy, Professor, Corresponding Member of NAES of Ukraine, Rector, State Higher

Education Institution "Kyiv National Economic University named after Vadym Hetman", Kyiv, Ukraine

Abstract. The problem of competitiveness of national higher education systems and ranking positioning of universities is highlighted based on the generalization of the world experience and empirical analysis. The key role of universities in the global ecosystem is shown, when intellectual capital becomes the main factor of the development and progress. Weak competitive positions of Ukrainian universities in the global rankings is confirmed and the potential for their increase is revealed. The foreign experience of state support for universities in the countries - innovative leaders is illustrated. The challenges and opportunities of digital transformation of universities in the format of network-platform competition in the global market of scientific and educational services are identified. The organizational design of the competitive model of a modern university is argued. Critically important contours and strategic guidelines of university development in the paradigm of "Higher Education 4.0" are substantiated.

Keywords: global competitiveness; global intellectualization; intellectual capital; higher education systems; universities; monitoring; digital transformation of universities; global networks; platform competition; educational paradigm 4.0.

Дата публікації: 30 грудня 2020 р. 